Прегледни научни рад УДК 31-09.(73)821.111 Набоков В.

Примљен: 31. марта 2021.

Прихваћен: 5. маја 2021.

Предраг П. Бребановић ${ }^{1}$

https://doi.org/10.46630/phm.13.2021.26

Универзитет у Београду

Филолошки факултет

\title{
ХАРОЛД И СЕБАСТИЈАН ${ }^{2}$
}

Као прво књижевно дело које је аутор написао на енглеском језику и публиковао у Сједињеним Државама, Стварни живот Себастијана Најта у опусу Владимира Набокова заузима по много чему посебно, мада међу тумачима недовољно препознато место. Уз констатацију да је посреди класичан „роман лика“ (В. Кајзер), у раду се пажња усмерава ка генолошком устројству и метафизичкој димензији самог штива. Притом се поставке и резултати биографске критике разматрају како у контексту романескног заплета, тако и у контексту релација између текстуалне и вантекстуалне онтолошке равни. У закључку се интерпретативни ослонац проналази у теорији стваралаштва Харолда Блума.

Кључне речи: Стварни живот Себастијана Најта, Владимир Набоков, Харолд Блум, елегијска романса, фикционална биографија

Владимир је Набоков код Харолда Блума редовно пролазио горе него што би се, имајући у виду блискост двају радикално естетицистичких светоназора и сазвучје пратећих strong opinions, дало наслутити. Истина, за писца се - више реда ради - нашло места на критичаревом ширем попису из Западног канона (The Western Canon: The Books and School of the

1 brebanov@eunet.rs

2 Пре нешто више од годину дана, вест о смрти Харолда Блума (Harold Bloom, 19302019) затекла ме је у припремама за Задарске филолошке дане. Сходно теми скупа, моје је излагање требало да буде посвећено проблематици књижевних ликова. Али, на оно на шта сам хтео да укажем већ неинвентивним насловом „Стварни лик Себастијана Најта“"ненадано је пала сенка стварне смрти некога кога сам до тада узимао за најбољег „живог“ књижевног критичара. Тако је излагање још у нацрту почело да губи фокус, постајући - помало непримерено - некролог Блуму. У свечаној сали задарског Филозофског факултета звучало је све то још непримереније, па сам при обраћању од једног тренутка почео да прескачем планиране сегменте о Блуму, настојећи да излагање приведем у мирну луку учености. Цена је била превисока, пошто сам услед временског ограничења испустио нит и готово у потпуности жртвовао набоковљевску метафизику - коју сам сачувао за ову пригоду. Као и своју посвету Блуму. 
Ages, 1994), камо су му доспеле само две славом ионако овенчане књиге. Блум је предност давао Бледој ватри, док је за Лолиту тврдио да јој је прва половина неупоредиво боља од друге. О томе сам писао у књизи о њему, очешавши се успут и о познату анегдоту са Универзитета Корнел. Тамо је критичар као студент походио пишчева предавања - од чега је, према накнадном сведочењу, дигао руке након што се особа за катедром негативно изјаснила о једном од ликова Џејн Остин. Скоро сви критичари-горостаси били су злопамтила, па се ни Блум неће уздржати од подсмешљиве опаске да му је Владимир Владимирович тада звучао попут Хамберта Хамберта, као ни од сурове оцене да „књига звана Лолита“ није ни изблиза онолико „памтљива“ илити канонска колико Гордост и предрасуда (уп. BREBANOVIĆ 2011: 146). Империје, макар и духовне, вазда узвраћају ударац - али каткада то обаве с вишедеценијском задршком.

Ипак, није спорно да су и Набоков и Блум према поетици књижевног лика гајили зачудно сличан, прецизније зачудно старомодан однос. Као што је давно запазио Џон Бејли, у зрелој се фази уметности романа класични лик повлачи пред свешћу, њеним преиспитивањем и иронизирањем; но, ни Набоков ни Блум никада нису раскинули с ливисовским, ad hominem поимањем карактеризације, којег је најистакнутија представница по Бејлију управо Џејн Остин, око чије се протагонисткиње Елизабет Бенет и њеног судара са светом јавило неслагање између њих двојице. Супротан би пример био Достојевски, пред чијом су се необузданошћу професори Набоков и Блум читавог живота успаничено склањали под Толстојеве очинске скуте. За разлику од Грофа (који ти експлицитно сугерише шта да мислиш о његовим стивама облонскима), као и од „новохуманистичких“ романописаца попут Олдоса Хакслија, Ангаса Вилсона или Сола Белоуа - чијим се карактеризацијама може спочитати становита крутост - Епилептичар није био заинтересован ни за какав (принципијелан или непринципијелан) коалициони дослух са читаоцима око ликова и њихових карактера. Испада да нам је Достојевски „показао пут“ (BAYLEY 1974: 234), омогућивши потоњим руским писцима (не искључујући ни оне из совјетске епохе, међу којима Бејли издваја Виктора Смирнова) да превазиђу модел „механичких духовности“ (232) каквом наводно нису успели да умакну ни ствараоци ранга Греама Грина, иначе једног од првих ватрених обожавалаца Лолите.

Збиља, колико год да се јесу грозили сваког механицизма, ни Набоков ни Блум нису тајили да уживају у списатељској контроли над ликовима - с тим да се први понашао као творац-апсолутиста, док је други био присталица нешто либералнијег законодавства. Обојица вам повремено делују као да трагају за малим људима по радио-апаратима, али би Блум тим створењцима, да се он пита, дикенсовски самилосно допустио да се (у складу са оним што је Хегел уочио код Шекспира) осамостале као „слободни уметници сами себе“, док би Набоков - чак и онда када им, као 
у Стварном животу Себастијана Hajma (The Real Life of Sebastian Knight, 1941), мути и меша животе и, релативизујући границе између њих, креира флуидне субјекте - хтео да остане њихов господар, неко ко их попут шаховских фигура миче како му се прохте. Поредио их је и са кметовима. Према школској класификацији Волфганга Кајзера, његови су романи - чак и када се не зову Машенка или Пнин, Лолита или Ада - најчешће „романи лика“. Упркос томе, Блум је био лош и нимало креативан читалац Набокова. Као крунски доказ довољно је навести да се Стварног живота Себастијана Најта (а приде ни пишчевог преводилачког рада, што је барем подједнако неопростиво) није ни дотицао. На укупно 588 страница његове књиге Романописиц и романи (Novelists and Novels, 2004) - којима нипошто не дефилују само генији и ремек-дела - од овог романа нема ни трага, ни гласа. Зато не изненађује што ниједан у мору томова из приређивачке серије Bloom's Major Literary Characters није посвећен Cебастијану. ${ }^{3}$ Изузимајући самог Племенитог Витеза, једини Најт којем се Блум клањао био је ексцентрични шекспиролог Џорџ Вилсон Најт, чија су „погрешна читања“, уз она Вилијама Емпсона, по њему „антитетичкија од свих других“ (BLOOM 1997: 95). Али ме ни то неће спречити да овде упризорим лотреамоновски сусрет свог омиљеног критичара са својим омиљеним романом, чију симболичку економију сматрам јединственом и непревазиђеном.

Међутим, осмишљавајући тај сиреалистички аранжман, схватио сам да звоно у тексту који тече неће звонити само за Блумом. Иако сам унапред одустао од призивања његовог тобожњег колеге и готово сапутника Џорџа Стејнера - са киме су му у једном лондонском магазину побркали фотографије, након чега ни један београдски дневни лист, извештавајући о смрти потписника Западног канона, није пропустио да понови исту трагикомичну грешку - „магија и логика“, упоредиве са онима што их је у хипнотичком магновењу следио приповедач Набоковљевог романа, навеле су ме на то да се у потрази за Себастијаном ослоним на двојицу набоколога за које се (а ту сам већ престао да верујем у постојање било какве случајности) испоставило да су умрли исте године. Ни Набокову ни Блуму - будући да су, скупа са не толико малим бројем паметних људи, радо препуштали гностичко-кабалистичким, унеколико и окултистичким спекулацијама о обрасцима који се понављају у људским и животима књижевних ликова - не би промакло да обојици презимена почињу словом „Б“. Звали су се Кенет А. Брафи и Генадиј Барабтарло; напустили су нас у јануару и фебруару 2019-е.

3 Једини мени познати изузетак Блум је начинио у склопу серије Bloom's Modern Critical Views, где је 1987. године изашла антологија критичких текстова о Набокову. Том приликом је у top ten приређивач уврстио и један урадак о Стварном животу Себастијана Hajma: друго поглавље из књиге Џулије Бејдер Кристална земља (Crystal Land: Artifice in Nabokov's English Novels, 1972), под индикативним насловом „Јединство у перцепцији“. 
За разлику од Блумовог, њихова бих читања Набокова блумовским језиком окарактерисао као „снажна погрешна“. Били су, и један и други, опседнути Стварним животом Себастијана Најта, о којем су обојица писали у више наврата. Брафијево је читање генолошко, док се Барабтарло - који је тај роман по трећи пут превео на руски (Истинная жизнь Севастьяна Найта, 2008), да би га у својој пред-смртној књизи ишчитавао упоредо са пишчевим снохватицама (Insomniac Dreams: Experiments with Time by Vladimir Nabokov, 2018) - определио за метафизику. Уколико питању о Најту као лику мора претходити одговор о књизи у којој он занавек обитава, онда нам ова двојица покојника у проналажењу тог одговора могу помоћи. Али, прво треба дефинисати проблем.

Стварни живот Себастијана Најта обично бива спомињан лапидарно, као прво дело које је аутор објавио на енглеском и које, самим тим, представља уводно поглавље другог дела његовог опуса. Настао је, не само по списатељевим мерилима, невероватно брзо: започет је поткрај 1938, а завршен већ 29. јануара 1939, два дана пре истека рока за предају рукописа на један лондонски конкурс. Набоков га је писао смрзавајући се, јер је у свом изнајмљеном париском станчићу као радну собу користио минијатурно купатило у којем му је као писаћи сто служио кофер постављен на биде. Резултат је било „најфранцускије“ романопишчево остварење (које је, као такво, тек почетком педесетих у Француској постало популарно) - али ће у мају 1940, свега три седмице пре уласка Немаца у Париз, писац са супругом и сином отпловити за Америку.

Према наводима његовог најупућенијег биографа, Едмунд Вилсон и Хари Левин су у јануару 1941. Набокова спојили с издавачем Џејмсом Лафлином, коме је рукопис Стварног живота Себастијана Најта убрзо стигао уз препоруку песника Делмора Шварца. ${ }^{4}$ „Након три године одбијања, Набоков није имао куд него да прихвати скромни аванс од 150 долара.“ (BOYD 1991: 33) Књигу ће наставити да прати лоша срећа, јер се у књижарама појавила 18. децембра, десетак дана након јапанске инвазије. Одуставши од свог дотадашњег псеудонима (Владимир Сирин), писац се у првом издању прозвао Vladimir Nabokoff.

Као предводник марксистичке књижевне критике у Америци и

4 Да ли коинциденцијом, презиме Шварц појављује се и у самом роману, и то на једној од најважнијих страница, коју ћу цитирати и у четвртом одељку. Како сазнајемо од приповедача, Шварц је љубазни, остарели шахиста из јунаковог ремек-дела Сумғичави Златоглав. Приповедач нам препричава сцену у којој старац „седа на столицу у соби, у кући, да би научио сироче како се помера скакач“ (NABOKOV 1964: 147). Три поглавља раније, исти се приповедач - јер Стварни живот Себастијана Најта одиста јесте hell of mirrors - у Паризу већ сусрео с дететом и двојицом шахиста, од којих један бива апострофиран као „Uncle Black“ (123). 
тадашњи ауторов велики пријатељ (а каснији љути непријатељ), Вилсон је био и остао уверен да се ради о нечем најбољем што је Набоков написао. Фланери О'Ќонор отишла је и корак даље, стварајући око Стварног живота Себастијана Најта прави мали култ. Упркос томе, ова особена биографија руско-енглеског писца (Себастијана), исприповедана из перспективе његовог полубрата (B-a), засигурно никада неће бити масовно читана. Њен је највећи хендикеп комплексност - подједнако садржајна и формална - која јој је уједно и највећа врлина.

Знамо колико је за модернистички роман битна матрица фикционалне биографије. Исто тако, знамо и да је модернизам ту матрицу рабио са циљем да поткопа не само вишевековну традицију романсираних биографија, него и позитивистички усмерени биографизам, који је у критици и историографији подразумевао узрочно објашњење књижевног дела пишчевим животом.

Обе ове критике присутне су у Стварном животу Себастијана Hajma. С једне стране, В. од самога почетка одбија концепцију „методичног континуитета“, називајући романсиране биографије „далеко најгором књижевношћу која је до данас смишљена“ (NABOKOV 1964: 17). С друге стране, разорно сатиричну критику психологистичког и социологистичког поимања књижевности писац нам сервира у лику Најтовог службеног биографа г. Гудмена, који је „у нескладу са својим јунаком у сваком делу приче“ (ibid). У седмом поглављу романа В. анализира Гудменову Трагедију Себастијана Најта, где он саิм није нити споменут. Оно је, дефинитивно, најдуховитије у књизи: приповедач се у њему окушава као критичар. Шегачећи се са Себастијановим „усиљеним“ животописцем и његовим несуптилним историзмом, он показује да је увелико постао следбеник свог полубрата, за кога време „није била 1914. или 1920. или 1936 - увек је била 1. година“ (55). Очито да Гудмен „није Бозвел“ (54), јер није кадар да појми дијалектику стваралачке субјективности на којој почива песничка егзистенција. ${ }^{5}$

Наравно да суштинско питање заправо гласи: да ли је могућ потпуно поуздан увид у нечију биографију? Још конкретније, али и ап-

5 Наредна пишчева књига биће Гогољев животопис (Nikolai Gogol, 1944), који је објављен исте године када и једна од његових неоправдано заборављених прича, компонована као фикционална биографија песника Константина Перова („A Forgotten Poet“). Четврт века доцније, Набокова ће погодити кармички бумеранг, јер ће тада - захваљујући томе што је живот, као и у случају описа цензуре у његовом (импресионистичким, односно поетизованим биографизмом Владислава Ходасевича надахнутом) роману Дар, почео да имитира уметност - доћи у конфликт с једним од својих биографа, услед чега ће као последњу властиту књигу, после више „стварних“, штампати жанровски једну зачудну, фикционалну аутобиографију (Look at the Harlequins!, 1974), која је у својој пародичности толико егоцентрично херметична да по мени, ако икаквог, има смисла само као аутофикционални, премда фикционалности у запањујућој мери лишен експеримент. 
страктније: „постоји ли трансцендентално означено Најтове биографиje?“ (RIMMON 1976: 492) Тако гледано, невоља са биографском критиком није у њеној заокупљености везама између „живота“ и „уметности“, него у томе што је „потпуно поуздан увид у нечију биографију“ немогућ. Одбијајући да се суочи са тиме, биографска је критика - иако је, за разлику од нпр. помињаног Кајзера (по коме песник није иманентан песми) исправно полазила од тога да сваки текст јесте биографско сведочанство - књижевно дело тумачила неким другим сведочанствима: такође биографским, али по правилу нижеразредним, ефемерним, баналним. У свом нес(п)ретном маниру, и В. тога постепено постаје све свеснији, да би напослетку дошао до истих оних уверења каква су присутна у многобројним Набоковљевим есејима, као и рецимо у париском јавном предавању које је (у години пре оне у којој је почео да пише Стварни живот Себастијана Најта) под покровитељством Габријела Марсела и у присуству Џејмса Џојса одржао под насловом „Пушкин, или стварно и веродостојно“ („Pouchkine ou le vrai et le vraisemblable“, 1937).

Наратолошки посматрано, Себастијанов се (не)стварни живот одвија на метадијегетичком приповедном нивоу, јер нам о њему приповеда В, који је и са̂м фикционални, дијегетички лик. Најтова дела (романи Призматична оштрица, Успех, Изгубъени иметак и Сумғичави Златоглав; приче „Смешна планина“, „Албини у црном“ и „Тамна страна Месеца“) творе, пак, мета-метадијегетички ниво, који, презентован цитатима и коментарима, запрема немали простор. Та се три нивоа узајамно одражавају, при чему се у игру укључује и четврти, екстрадијегетички. Мимо обичаја, од њега није бежао ни са̂м аутор, који је у својим трећим и последњим мемоарима, говорећи о властитом брату Сергеју, осетио потребу да нагласи како „[о]на закучаста потрага за Себастијаном Најтом (1940), са својим глоријетама и самоматирајућим комбинацијама, заправо није ништа у поређењу са задатком којем сам умакао у првој верзији ових мемоара и с којом сам сада суочен“.

Али проблем - као што се лепо види из читања Шломит Римон није у аналогијама, нити у самом непоузданом приповедању, временској вртешци, преокретима, двосмисленом расплету... него у прожимањима

6 NABOKOV 1966: 257. Сергеј Набоков (1900-1945), дотични пишчев брат, страдао је у концентрационом логору. Не само да је и он писао поезију, него му је живот био загонетан на начин који је - захваљујући томе што су им у зрело доба контакти, изузимајући париски период, били спорадични - Набокова привлачио и притискао. Бројне епизоде из пишчевих мемоара, примерице она о страсти према тенису коју су делили, потврђују да је однос између Владимира и Сергеја умногоме наликовао односу између В-а и Себастијана (уп. NABOKOV 1966: 257-258 ca NABOKOV 1964: 28-29). Аналогију потцртавају и иницијали романескних ликова, премда смо из Набоковљеве преписке с биографом из претходне фусноте дознали да је пуно име Најтовог полубрата, према творчевој замисли, било - Виктор. Најзад, истраживањем рукописне заоставштине утврђено је да се у најранијој етапи рада на роману В. звао Џорџ (уп. BARABTARLO 2008: 75-77). 
илити онтологији. Са одмицањем романа, границе између приповедача и јунака толико се замагљују да је читалачка вртоглавица неминовна. Рађају се и ређају недоумице: ко води игру? Нису ли се два главна лика стопила, а нарација преточила у хомодијегезу? Можда конце приче повлачи са̂м Себастијан, као што hе у Бледој ватри то по некима радити Џон Шејд? Није ли В. једнако неодољив (и неумољив) као што ће то бити Чарлс Кинбот? Да ли је пред нама фикционална аутобиографија? Чија, Себастијанова или В-ова? В-ова, али вођена Себастијановим духом?

Наратологија вам можда може помоћи да се снађете у описаној игри одражавања и евентуално спроведете одговарајуће квантитативне анализе - којима је установљено да су 44 романескна сегмента превасходно посвећена Себастијану, 51 В-овој потрази, док се 17 тичу обојице, при чему се у темпоралној димензији догађа преусмеравање читалачке пажње са јунака на приповедача - али не и да схватите шта се дешава при проласку кроз зрцало. Отуда је помињана интерпретаторка била принуђена да искорачи изван теорије приповедања и позове се не само на лакановски стадијум огледала, него и на идеју да не постоји метајезик.

Другим речима, од силних тумачења биографских, психолошких или интертекстуалних (међу којима су у последње време најдрагоценија она усредсређена на Шекспира) - као ни од, нажалост, разочаравајуће књиге Присиле Мејер, Набоков и неодређеност (Nabokov and Indterminacy: The Case of The Real Life of Sebastian Knight, 2018), у којој се помоћу бледуњавих кључних појмова и преслабих поенти подгревају тезе о постмодернизму - нема превише вајде. А изгледа да за то, како је још пре пола столећа открио Брафи, кривац није нико други до Џорџ Гордон Бајрон. ${ }^{7}$ Ево зашто.

\section{III}

Занесен вампирским заплетом којег је уобличио његов приватни лекар, Бајрон је својом недовршеном хорор-приповешћу „Фрагмент једног романа“ („Fragment of a Novel“, 1819) - као и, пре тога, трећим певањем Чајлда Харолда (1812), али и ненадмашним Манфредом (1817) - врата романсе широм отворио за елегију. У „Фрагменту...“, безимени младић путује на Исток заједно са извесним Августом Дарвелом; потоњи на путовању умире, да би уследило мноштво чудних и застрашујућих збитија. По Брафију је то праобразац „елегијске романсе“ (elegiac romance), коју он сагледава у бразди традиције „романсе потраге“ (quest romance), чији је репрезентативни изданак и Стварни живот Себастијана Најта.

Горњи су појмови дакако преузети од Нортропа Фраја (уп. FRYE 2000: 37 и 189), али се Брафи надовезује и на ревизионистичке интервен-

7 Читатељкиној пажњи препоручујем чињеницу да се слово „Б“ јавља као почетно у натполовичној већини (седам од укупно 12) библиографских јединица из „Цитиране литуратуре“с краја овог текста. 
ције које је, као најкреативнији следбеник творца Анатомије критике (1957), Блум извршио најпре у тексту „Поунутарњење романсе потраге“ („Internalization of the Quest Romance“, 1968), а онда и у Cmpaxy od ymuu,aja (The Anxiety of Influence: A Theory of Poetry, 1973).

Све је почело с Парсифалом - аристократским трагаоцем који у првој фази стреми да „надвлада слабост властитог карактера како би заслужио племениташки статус и осигурао репутацију витешке галантности и храбрости“ (BRUFFEE 1983: 32). У другој фази, код Сервантеса долази до крупне промене у самој структури потраге, пошто Дон Кихот више није усамљен на романескној позорници, где се благодарећи Санчу Панси као нови моменти појављују мимикрија, конфузија и иронија. Потом следи и кључна, бајроновска иновација, која се у трећој фази историје истог типа уметничке прозе састојала у заокрету ка свакодневном искуству и измештању тежишта са јунака на приповедача, са витеза на штитоношу. Док је у Дон Кихоту, где је у пародијско-витешком коิду уведена дијалектика двају ликова, фокус свезнајуће наративне инстанце и даље био на хероју, Енглез своју причу започиње онако како је Шпанац окончава: витезовом смрћу. ${ }^{8}$ Паралелно са тиме, сукоб части претвара се у сукоб осећања, а акценат помера ка теми идентитета, при чему опсесивна младићева жеља за поистовећивањем с узором - као што је показао Блум - представља извор анксиозности и метафизичког набоја. Зато Брафи поводом Чајлда Харолда говори о „синтетичком јунаку“, док смо ми у искушењу да спиритуални заплет који нас занима назовемо Чајлд Харолд Блум. Како било, са Бајроном романса постаје елегична, али се и удаљава од наслеђа пасторалне елегије (лирске подврсте која одише достојанственим спокојством и чији је канонски продукт, не само по Блуму, Милтонов Лисидас [1638]), те стиче „потенцијал за структуралну еволуцију“ (BRUFFEE 1983: 38).

Тај ће потенцијал бити реализован тек у четвртој фази, када ће романтичарски crossover напокон набујати у магистралну елегијску струју модерне западне књижевности, којом су запловили и Моби Дик (1851), и Срие таме (1899), и Добар војник (1915), и Велики Гетсби (1925) и Сви кратеви тьуди (1946), и Доктор Фаустус (1947)... па и Стварни живот Себастијана Најта, као и, добрим (бољим?) делом, Бледа ватра (1962). У сваком од ових романа, приповедач вам - био он Ишмаел или Марлоу, Дауел или Каровеј, Бурден или Цајтблом, В. или Кинбот... - о некој мртвој особи - била она Ахаб или Курц, Ешбурнам или Гетсби, Старк или Леверкин, Најт или Шејд... - приповеда као о пројекцији властите душе, 8 У том је погледу спомена вредно да је Миливој Солар есејистички разабрао да је Санчу после нестанка велеумног племића преостало само то да постане романописац, што је током три века уистину и био. Да би онда и он - умро: „Romanopisac je, dakle, rođen u romanu, i u romanu je umro kao 'rođeni romanopisac' onog trenutka kada je pripovijedanje izgubilo svoj oslonac u onome što se ne može ispripovijedati jer svakom pripovijedanju služi kao nacrt zacrtan na stvarnom tlu povijesne zbilje." (SOLAR 1981:31) 
при чему га са̂м чин приповедања, који је уједно и превазилажење губитка, искупљује и неумитно води ка катарзи. ${ }^{9}$

Тако се и В, пишући о Себастијану, уздиже до „унутрашњег разумевања“ - у чему препознајемо ехо исте оне „унутрашње истине“ о коjoj у Сриу таме медитира Марлоу. Питати се да ли је Набоков тога био или није био свестан једнако је умесно колико и бити убеђен да заплет Лолите почива на томе што размажено дериште малтретира уљудног одраслог белца. Nota bene: не само да се трговачки путник из првог Себастијановог романа зове Парсивал К; и не само да нам у сцени јунаковог љубавног растанка В. евоцира један Бајронов сан; него нам у делу цитирано бива и писмо у којем се Себастијана прекорева што пише исувише „конрадовски“ и предлаже му се да избаци „кон“, како би се посветио узгајању „рада“. ${ }^{10}$

Укратко, идеал-типска елегијска романса није ништа доли наративни лукк који се протеже од јунакове смрти до приповедачеве самоспознаје. Посреди је поджанр у којем наратор стиче, односно (раз)открива сопствени идентитет посредством приче о некоме кога обожава, коме се диви, киме је фасциниран. Сама прича може бити извештај о егзотичној авантури или сентиментална исповест; може садржавати приказ непатворене људске монструозности или сабласно нарастајућег опортунизма; може, као у Грађанину Кејну (којег, не знам зашто, нико до сада није препознао као један од врхунаца ове традиције), маестрално обједињавати побројане фабуларне саставнице; а може, као у Стварном животу Себастијана Најта - штампаном у години у којој је снимљен Велсов филм отеловљавати тежњу да се имагинативном реконструкцијом прошлости одгонетне интимна и стваралачка тајна генијалног писца. Ето због чега В. очајнички жели да сазна ко је била последња жена коју је Себастијан волео.

\section{IV}

Наш други интерпретатор-помоћник покушао је да тај вео тајновитости скине у тексту којег је насловио прелепим анаграмом „Таина Наита“. Анаграми су били Набоковљева специјалност, услед чега се и Барабтарлово тумачење романа заснива на открићу да слова из јунаковог имена крију кључ. Напросто, SEBASTIAN KNIGHT, уз елиминацију јед-

9 Примери краћих прозних творевина истог профила крећу се у широком распону од Пушкиновог „Хица“ (1831) и Поовог „Пада куће Ашерових“ (1839), преко Кафкине „Певачице Јозефине или народа мишева“ (1924) и Фокнеровог „Ујка Вилија“ (1935), до Борхесовог „Фунеса памтиоца“ (1942) и Ландолфијеве „Гогољеве жене“ (1954) - коју ће Блум прогласити једном од најсмешнијих, али и најузнемирујућих прича у свеколикој књижевности.

10 „Јединствено будаласта идеја, мислио сам“ (NABOKOV 1964: 33) - поентираће приповедач, потврђујући да је наш интерпретатор-помоћник био на правом трагу. 
ног „а“, даје KNIGHT IS ABSENT.

За разлику од Брафија, Барабтарло верује да у роману постоји идентитетска слагалица и да нам је за разрешење мистерије неопходан улазак у набоковљевску метафизику. По њему, ми у Стварном животу Себастијана Најта немамо посла с фикционалном биографијом или аутобиографијом, већ с експерименталном прозом илити онтолошком фикцијом заснованој на визији која је добила безмало математички тачан израз. Игру не води ниједан од полубраће, јер су обојица плод неке треће текстуалне имагинације и њеног свепрожимајућег смисла, који премошћује границе међу световима и „стварностима“. При оваквом читању роман се претвара у еманацију нечега што је у набокологији посве адекватно било крштено опти-мистицизмом, док се питање јунаковог статуса сагледава у координатама са завршетка књиге, где након одломка из Најтовог Сумғичавог Златоглава следи овај В-ов коментар:

Човек умире, и он је јунак приче; али док животи осталих људи у књизи изгледају савршено стварни (или барем стварни у најтовском смислу), читалац не сазнаје ко је човек који умире, ни да ли његов одар стоји или плута, ни да ли је уопште одар. Човек је књига, сама књига се уздиже и понире, и усправља се уз подерано колено. Једна мисаолик, затим још једна, разбија се о обалу свести и ми пратимо ствар или биће које смо оживели: залутали остаци насуканог живота; трома маштања која пузе а затим шире скупљена крила. (NABOKOV 1964: 147)

Човек је књига - Барабтарло не одолева да у овим речима препозна пишчеву формулу и пригрли је. Као у Грађанину Кејну, када повежете „те палате, и те слике, и те играчке, и све остало“, добијете Чарлса Фостера Кејна - чије су санке, попут Себастијанове преписке, нестале у пламену. У епилогу Твориа (El Hacedor, 1960), Хорхе Луис Борхес је то дочарао овако:

Čovjek se poduhvaća zadaće da opiše svijet. S godinama, napučuje prostor slikama pokrajina, kraljevstava, planina, zaljeva, brodova, otoka, riba, soba, oruđa, zvijezda, konja i ljudi. Malo prije negoli umre, otkriva da taj strpljivo izrađeni labirint od crta riše sliku njegovog lica. (BORGES 1985: 86)

Да, биће да је таква била и ауторова намера. Али, не заборавимо да је са̂м Набоков, зачудо, држао да Стварни живот Себастијана Најта пати од неподношљивих слабости и да је творац те књиге-лавиринта самога себе „матирао“у њој. Уколико је исход заиста такав, мислим да знам и како је мат изведен: никако другачије него коњем - jep je knight, осим за витеза, и ознака за скакача. Артистичка контрола је заказала, скакач оживео. Одсутан (побеђен) је Набоков, не Најт. Себастијан је присутан, он је она „ствар или биће које смо оживели“. Физички је мртав, али - како и В. вели - „насмејано жив у својих пет књига“ (NABOKOV 1964: 44). 
И ту стижемо до последњег завијутка, где нас коначно дочекује Блум и изводи из лавиринта. У свакоме од нас чучи демон „закаснелог“поучава он. Није ли В. онај блумовски, пословично „идиотски“ читалац који, откривајући Себастијанову тајну као тајну сопственог херувима заклањача, израста у закаснелог писца? Зар се на страницама Стварног живота Себастијана Најта не одвија арpophrades - то јест, драма повратка из мртвих илити поновног рађања снажног песника? Снажан песник, по Блуму, не може са̂м да се роди, већ мора да причека сина. Или млађег полубрата? Мајка је, стоји у Страху од утицаја поводом Блејка, „песников замишљени дух или идеја о сопственој узвишености, а оца ће наћи тек кад нађе свог правог ефеба, који ће га ретроспективно зачети с музом, да би она коначно тада постала његовом мајком“ (BLOOM 1997: 61).

Себастијан је постао Најт тако што је узео мајчино презиме као псеудоним: немају ли полубраћа истог оца и зар њихова породична романса није подједнако животна (биолошка) и списатељска (духовна)? И не остаје ли нам, на крају, само то да заједно с Блумом закључимо како једина истинска песничка историја „говори о томе како су песници трпели друге песнике, као што и свака истинита биографија прича о томе како је неко трпео своју породицу - или је заменио љубавницима и пријатељима“ (94)? Због чега ли је Блум гледе Набокова уопште могао заобићи следећу властиту реченицу, која као да је написана само да би осветлила пишчев роман:

Снажан песник зури у огледало свог палог претходника и у њему не види ни њега ни себе већ гностичког двојника, мрачну другост или антитезу, оно што су се обојица плашили да постану, мада су желели. $(147)^{11}$

Стварни живот Себастијана Најта је, више но било које Набоковљево штиво, прожет блумовским гностицизмом. ${ }^{12}$ И зато нам се тек у пресеку свих назначених (набоковљевским наводницима нужно опремљених) „стварности“, у величанственом споју елегијског књижевног модуса са метафизиком књиге, оцртава Себастијанов лик. Јер Харолд је Себастијан, или је Себастијан Харолд, а можда су обојица ја или неко други кога не познају.

11 Не могу да не приметим да се и бројеви страница у издањима Стварног живота Себастијана Најта и Страха од утицаја која цитирам поклапају. Као и да се Бејлијеви мемоари зову Елегија за Ајрuс (Elegy for Iris, 1999).

12 За тај гностицизам види BREBANOVIĆ 2011: 299-323. Блум је написао и „gnovel“ под насловом Лет на Луцицфер (The Flight to Lucifer: A Gnostic Fantasy, 1979). 


\section{Цитирана литература}

BARABTARLO 2008: BARABTARLO, Gennady. „Taina Naita. Narrative Stance in Nabokov's The Real Life of Sebastian Knight“. Partial Answers: Journal of Literature and the History of Ideas 6, 1, 57-80, 2008.

BAYLEY 1974: BAYLEY, John. „Character and Consciousness“. New Literary History 5, 2, 225-235, 1974.

BLOOM 1997: BLOOM, Harold. The Anxiety of Influence: A Theory of Poetry (Second Edition). New York \& Oxford: Oxford University Press, 1997.

BORGES 1985: BORGES, Jorge Luis. Sabrana djela (1952-1969). Prevod grupe prevodilaca. Zagreb: Grafički zavod Hrvatske, 1985.

BOYD 1991: BOYD, Brian. Vladimir Nabokov: The American Years. New Jersey: Princeton University Press, 1991.

BREBANOVIĆ 2011: BREBANOVIĆ, Predrag. Antitetički kanon Harolda Blooma. Beograd: Fabrika knjiga, 2011.

BRUFFEE 1983: BRUFFEE, Kenneth A. Elegiac Romance: Cultural Change and Loss of the Hero in Modern Fiction. Ithaca: Cornell University Press, 1983.

FRYE 2000: FRYE, Northrop. Anatomy of Criticism: Four Essays. With a new foreword by Harold Bloom. Princeton \& Oxford: Princeton University Press, 2000.

NABOKOV 1964: NABOKOV, Vladimir. The Real Life of Sebastian Knight. Harmondsworth: Penguin Books Ltd, 1964.

NABOKOV 1966: NABOKOV, Vladimir. Speak, Memory; An Autobiography Revisited. New York: G. P. Putnam's Sons, 1966.

RIMMON 1976: RIMMON, Shlomith. „Problems of Voice in Vladimir Nabokov's The Real Life of Sebastian Knight“. PTL: A Journal for Descriptive Poetics and Theory of Literature 1, 489-512, 1976.

SOLAR 1981: SOLAR, Milivoj. Smrt Sancha Panze: ogledi o književnosti. Zagreb: Nakladni zavod Matice hrvatske, 1981.

Predrag P. Brebanović

\section{HAROLD AND SEBASTIAN}

As the author's first literary work to have been written in English and published in the United States, The Real Life of Sebastian Knight holds a rather particular place in the oeuvre of Vladimir Nabokov, even if this seems to have escaped the notice of its interpreters. Contending that it is an exemplary „character novel“ (W. Kayser), the paper proceeds to focus on the generic construction and metaphysical aspect of the text. The premises and insights of biographical criticism are brought to bear on the plot, as well as on the relations that obtain between the textual and extra-textual ontological planes, while the conclusion is predicated upon Harold Bloom's theory of the creative act.

Keywords: The Real Life of Sebastian Knight, Vladimir Nabokov, Harold Bloom, elegiac romance, fictional biography 